\section{EREM 73/3}

Journal of Environmental Research, Engineering and Management Vol. 73 / No. 3 / 2017 pp. $32-44$ DOI 10.5755/j01.erem.73.3.16268 (C) Kaunas University of Technology
Impact of Wastewater Treatment Plant on Water Quality of the River Mažoji Sruoja, Plunge District
Accepted after revision 2017/09

\title{
Impact of Wastewater
}

\section{Treatment Plant on Water}

\section{Quality of the River Mažoji}

Sruoja, Plungè District

\section{Laima Česonienè}

Institute of Environment and Ecology, Aleksandras Stulginskis University, Studentu 11, LT-53361, Academy, Kaunas district

\section{Midona Dapkienè}

Institute of Hydraulic Engineering, Aleksandras Stulginskis University, Studentu 10, LT-53361, Academy, Kaunas district

\section{Daiva Šileikienè}

Institute of Environment and Ecology, Aleksandras Stulginskis University, Studentu 11, LT-53361, Academy, Kaunas district

\section{Vaiva Rekašienè}

UAB Plungès vandenys, Medelyno 41, Noriškių k., Plungès raj., LT-90103

\section{Corresponding author: laima.cesoniene@asu.lt}

Institute of Environment and Ecology, Aleksandras Stulginskis University, Studentu 11, LT-53361, Academy, Kaunas district

Lithuanian surface water bodies are negatively affected by diffuse pollution from agricultural activity and point source pollution, which results in an urgent problem - pollution with biogenic materials. A major part of point source pollution reaches surface water bodies together with domestic wastewater from Lithuanian towns and cities. The article analyses the impact of a wastewater treatment plant (WWTP) on water quality of the River Mažoji Sruoja, Plunge district. Essential differences at $100 \mathrm{~m}$ distance above the wastewater discharger and $500 \mathrm{~m}$ below the wastewater discharger according to total phosphorus, total nitrogen and ammonia nitrogen were established in the water of the River Mažoji Sruoja. Plunge City wastewater has an impact on the water quality of the River Mažoji Sruoja. A statistically significant positive correlation $(p<0.05)$ was identified between treated wastewater and concentration indices of the tested river water quality below the discharger of 
the wastewater treatment plant. Water quality of the River Mažoji Sruoja changed in different seasons of the year. A change in nitrogen compound content mostly reflected seasonal changes in the River Mažoji Sruoja. Major concentration of the materials was established during the cold period and minor during the warm period. Maximum $\mathrm{BOD}_{7}$ values were determined in summer and minimum in winter. The total phosphorus seasonal fluctuation was insignificant.

Keywords: wastewater treatment plant discharger, river water quality, biogenic materials.

\section{Introduction}

Human agricultural activity and its development have an inevitable impact on the environment. In order to avoid the impact of pollution emission on the environment, the European Union adopted two directives: the Nitrates Directive $(1991 / 696 / E C)$ and the Water Framework Directive (2000/60/EC). The aim of implementation of the directives is to protect all water bodies against anthropogenic interference (Kronvang et al. 2008).

Both diffuse pollution, the essential part of which consists of a load of pollutants generated during agricultural activity, and point source pollution, which results in pollution with biogenic materials, has a negative impact on the state of Lithuanian surface water bodies. In order to reduce the impact of concentrated pollution on surface water bodies, Lithuania has been implementing the Directives of the European Council and other legal acts.

The major part of diffuse pollution reaches surface water bodies together with domestic wastewater from Lithuanian towns and cities; however, their quantity has been regularly decreasing for the last decade. Increased efficiency of wastewater treatment plants has predetermined a decrease of discharges pollutants (Ministry of Environment 2012).

The river water quality is characterised by the content of organic and biogenic materials in water bodies and bacteriological indices. Nitrogen and phosphorus are highly important materials for water life. The concentration of these components and their change are predetermined by biological and biochemical processes occurring in water. A great amount of biogenic materials has a negative impact on the environment, because it results in surface water body eutrophication (Kronvang et al. 2005, Burkholder et al. 2007).
Washout of biogenic materials is predetermined by such natural factors as the amount of precipitations and seasonality. It has been observed that during the periods of increased abundance of water, the content of nutrient materials in the river water is greater, because such conditions are favourable for washout of nutrient materials and migration together with ground and surface water (Bagdžiūnaitè-Litvinaitienè and Lukianas 2004).

Organic materials usually contain solid particles, which have an impact on benthos of water bodies and cause changes in fauna species composition (Cooper 1993). Pollution sufficiently worsens the state of water ecosystems, reduces the possibilities to use water for various purposes and constitutes hazard for human health (Burkholder et al. 2007). A number of studies have considered assesment of the ecological status of surface water bodies (Kelly et al. 2009, Noges et al. 2009, Matysik et al. 2015).

It is reasonable to analyse changes in the quality of a surface water body and evaluate anthropogenic and natural factors. Changes in water quality of various European rivers and changes in the intensity of human activity have been studied. It has been established that a decrease in nitrogen entering the river from pollution sources does not reflect the change immediately (Grimvall et al. 2000).

In Lithuania, the impact of pollution sources on the quality of water in the Rivers Venta and Mūša-Lielupe basins has been evaluated (Vincevičienè and Asadauskaite 2000, Ruminaite 2010) and the impact of Kaunas City wastewater on the quality of Nemunas water has been assessed (Jurjoniene and Valatka 1997). The research results demonstrated that the impact of anthropogenic sources was $73 \%$ and $56 \%$ 
(according to $\mathrm{COD}_{\mathrm{Cr}}$ and $\mathrm{BOD}_{7}$ ) of the total borne organic material content in the River Merkys. Human activity predetermines $90 \%$ of the annual borne total nitrogen and $78 \%$ of the total phosphorus content (Povilaitis 2008). It is highly important to study the impact of pollution on the quality of water of small rivers, as these rivers are sensitive to probable changes of natural factors and anthropogenic activity and especially to concentrated pollution. Discharging municipal wastewater into a small river with low dilution capacities (especially during the dry season of the year) has a significant impact on the river water quality.

The aim of the paper was to determine the impact of the wastewater treatment plant on the water quality of the River Mažoji Sruoja in the city of Plunge by evaluating the seasonality factor.

\section{Methods}

Mažoji Sruoja is the right-bank tributary of the River Minija. The length of Mažoji Sruoja is $8.8 \mathrm{~km}$, and the basin area is $15.2 \mathrm{~km}^{2}$ (Figure 1). Two tributaries Sraujele and Mergvagis - flow into the river (Galiušis et al. 2001). The upper course is regulated, and the bottom flows into the ichthyologic reserve of Minija, as this is an important fish breeding area.

Part of point source pollution from Plunge flows into the River Mažoji Sruoja. During activity monitoring in 2006, we received poor results in Mažoji Sruoja mouth: the amounts of phosphate and total phosphorus showed a poor ecological state, and the amounts of $\mathrm{BOD}_{7}$ and ammonia nitrogen yielded a satisfactory

Fig. 1

Mažoji Sruoja basin

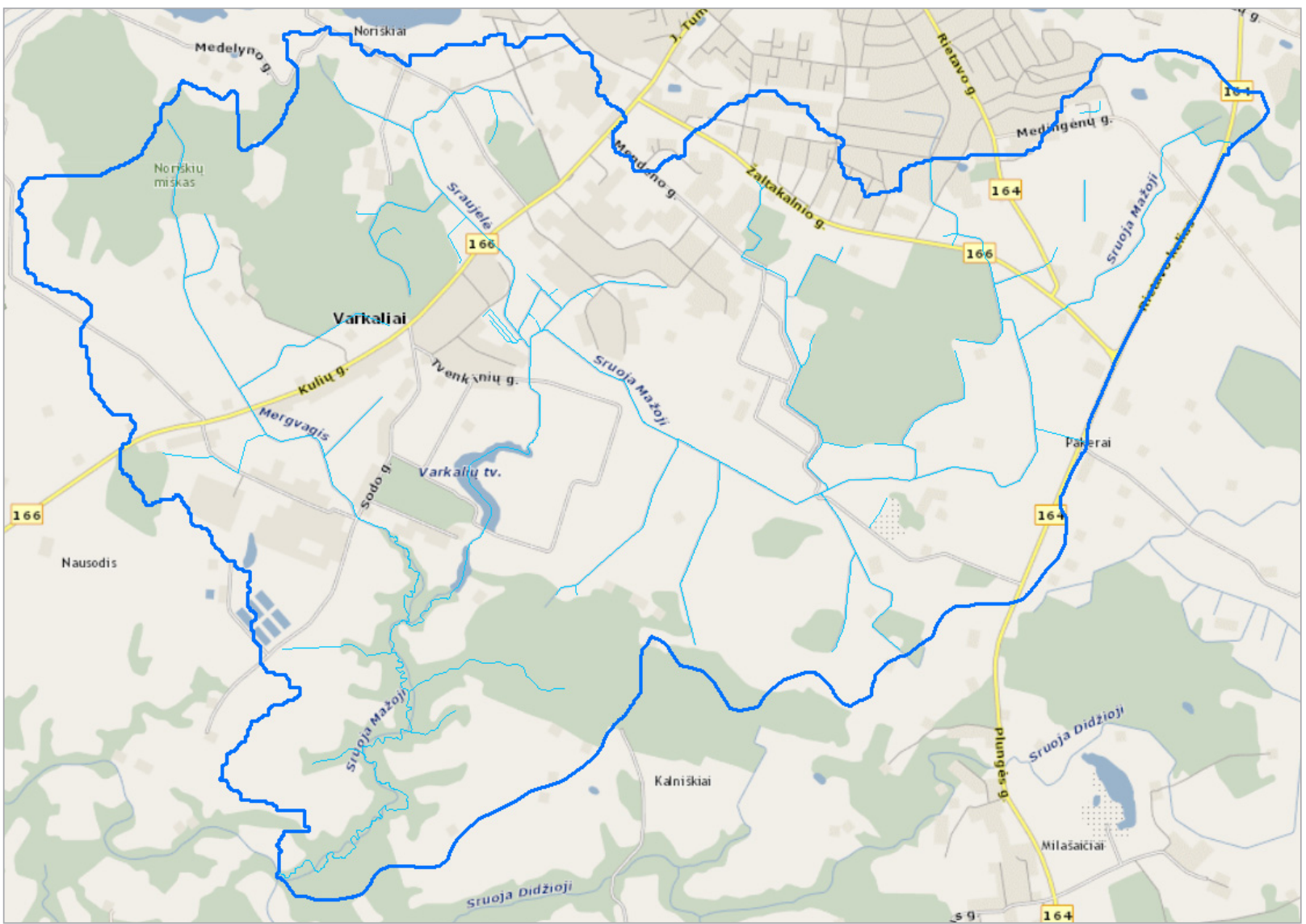


Fig. 2

Principle sampling diagram

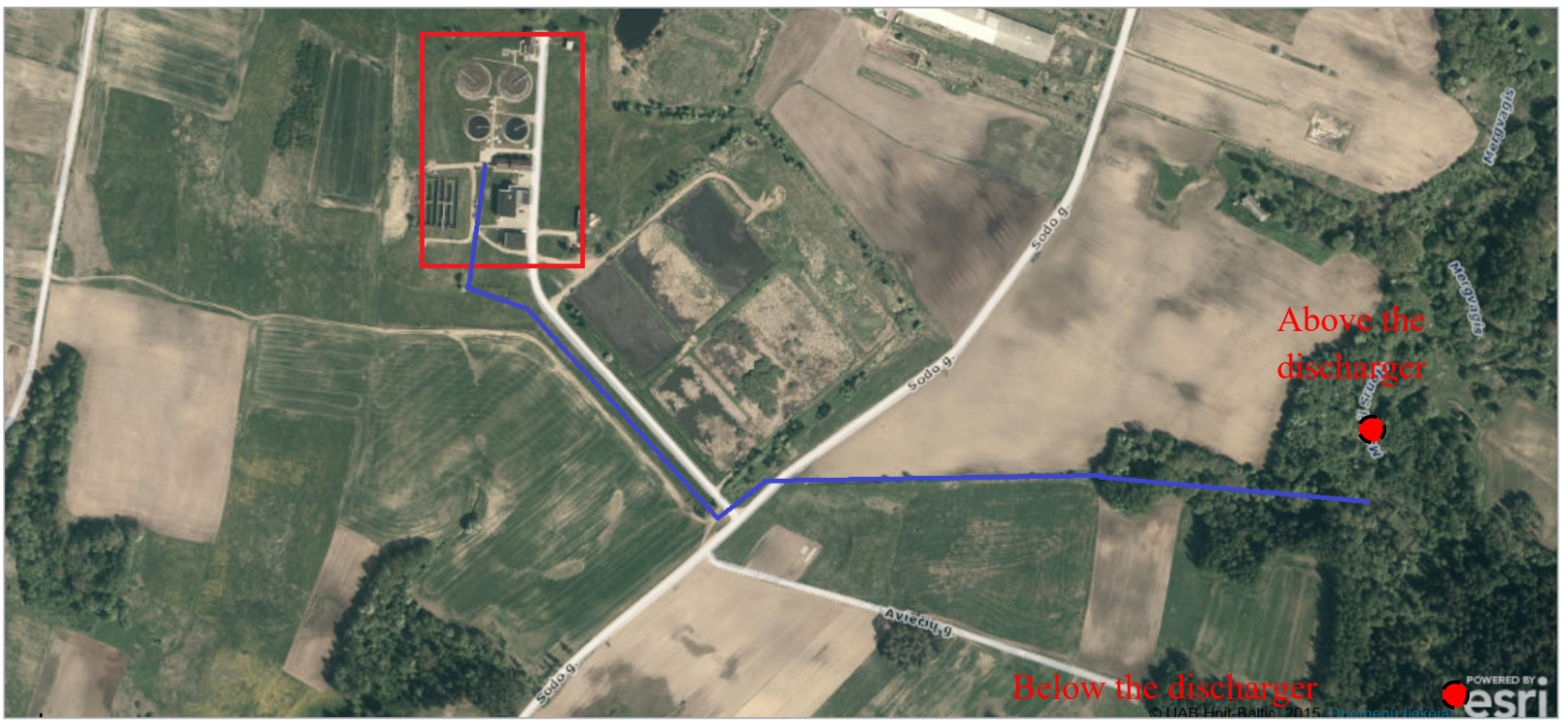

state (EPA 2007). An old wastewater treatment plant of Plunge operates inefficiently; nitrogen and phosphorus are not removed. In 2008, the wastewater treatment plant was reconstructed and, as it was specified, the quality of its treated wastewater met the established environmental safety requirements. Considering its short length and the flow rate of the river, it is important to study the impact of wastewater pollution on the quality of Mažoji Sruoja water.

River water sampling places were selected considering comfortable and safe access during all seasons of the year. The first place was selected at the distance of $100 \mathrm{~m}$ above the discharger, where the treated wastewater of Plunge has no impact on the river water quality. The second place was chosen where the wastewater is mixed with the river water - at the distance of $500 \mathrm{~m}$ below the treatment plant discharger (Figure 2).

Sampling places were selected to avoid diffuse pollution from the surrounding area. The analysis was carried out in the chemical analysis laboratory of $U A B$ Plungés vandenys using special laboratory equipment. The data of 2008-2014 were considered. The samples for the analysis were taken once per month. The most important water quality indices were analysed using standard methods: biochemical oxygen demand $\left(\mathrm{BOD}_{7}\right)$ (LAND 47-1:2007); ammonia nitrogen (LAND 38:2000); total nitrogen (TN) (LAND 84-2006); and total phosphorus (TP) (LAND 58-2003).

Changes in all indices were assessed using the linear trend and determination coefficient. The difference between water and wastewater indices above and below the discharger was assessed with STATISTICA 10 software, using the Student criteria. The difference was significant, when $p<0.05$. The impact of meteorological conditions and wastewater on water quality was assessed by calculating the correlation coefficient using STATISTICA 10 software. The river water quality was assessed according to physical and chemical quality component indices referred to the river ecological state rate (Ministry of Environment 2011).

\section{Results and discussion}

\section{Mažoji Sruoja water quality changes above and below the wastewater discharger}

The conformity of Mažoji Sruoja to the ecological state rate according to the values of physical and chemical 
quality components above and below the discharger in 2009-2014 are provided in Figure 3.

According to the TP content in the water above the discharger, Mažoji Sruoja meets good and very good values of ecological state class indices, and below the discharger - the values of ecological state class indices. The maximum permissible TP value, demonstrating a satisfactory good and very good ecological

Fig. 3

Values of physical and chemical quality components above and below the discharger in 2009-2014
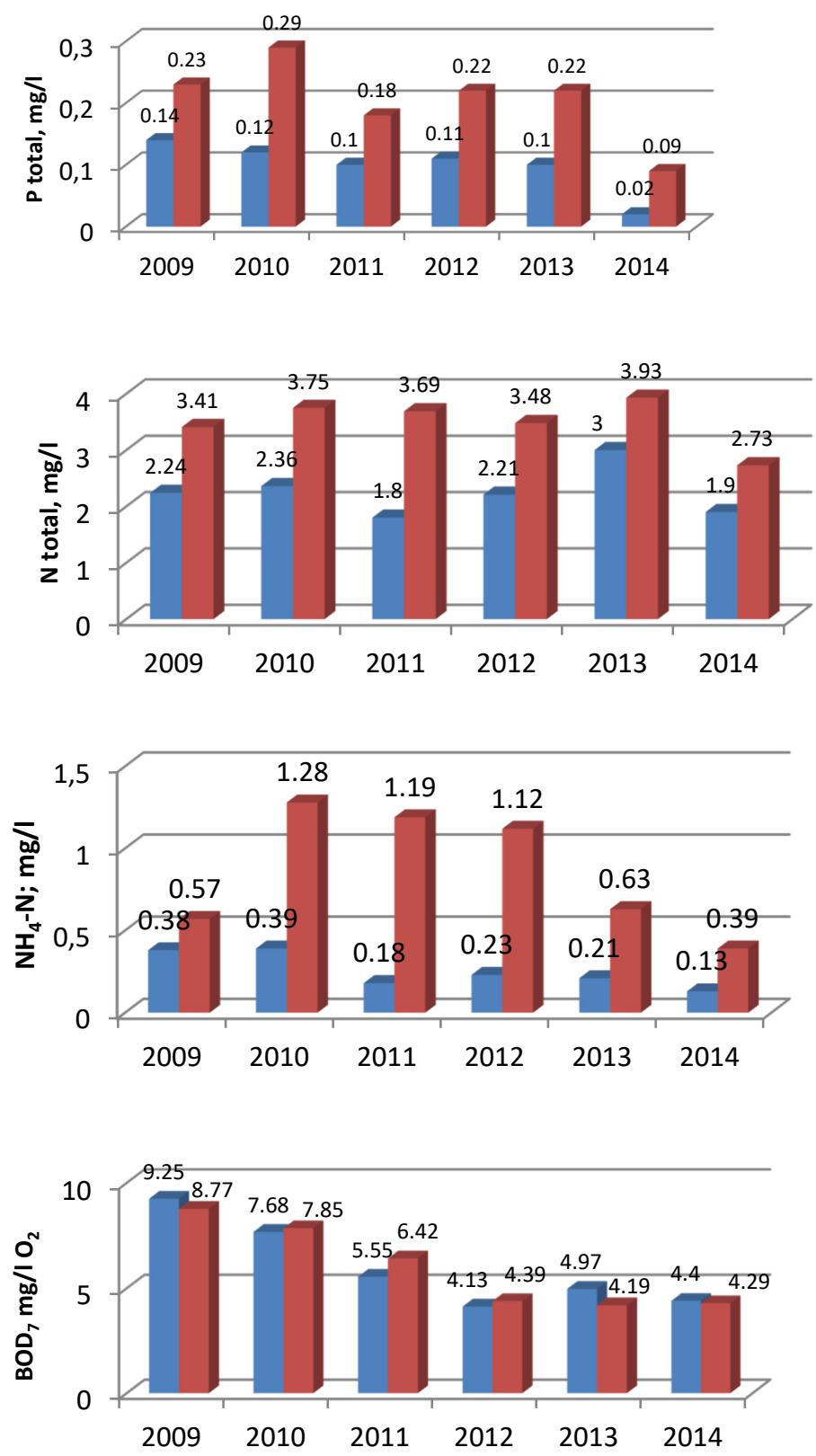

Above the wastewater treatment facility discharger

Below the wastewater treatment facility discharger

Above the wastewater treatment facility discharger

Below the wastewater treatment facility discharger

- Above the wastewater treatment facility discharger

Below the wastewater treatment facility discharger

Above the wastewater treatment facility discharger

Below the wastewater treatment facility discharger 
state $(0.1 \mathrm{mg} / \mathrm{L})$ below the discharger, was exceeded in all the research cases. We established an essential statistically significant difference between TP values above and below the wastewater discharger ( $t>0.05$ ).

According to the ammonia nitrogen content in the water above the discharger, Mažoji Sruoja meets good and very good values of ecological state class indices, and below the discharger - satisfactory and poor values of ecological state class indices. We established an essential statistically significant difference between $\mathrm{NH}_{4}-\mathrm{N}$ values above and below the wastewater discharger ( $\mathrm{t}>0.05$ ).

According to the TN content in the water above the discharger, Mažoji Sruoja meets good and very good values of ecological state class indices, and below the discharger - satisfactory values of ecological state class indices. We established an essential statistically significant difference between $\mathrm{TN}$ values above and below the wastewater discharger $(\mathrm{t}>005)$.

Almost during the whole research period, two sampling places of Mažoji Sruoja met satisfactory and very poor values of ecological state class indices according to $\mathrm{BOD}_{7}$ values. Especially high $\mathrm{BOD}_{7}$ values were determined in 2011, probably because of insufficient stability of recently reconstructed wastewater treatment facility operation. No difference was established between the values above and below the discharger $(t<0.05)$.

Summarising the results of Mažoji Sruoja water quality analyses in 2008-2014 at the distance of $100 \mathrm{~m}$ above and $500 \mathrm{~m}$ below the wastewater treatment facility discharger, we can state that there are essential pollution differences above and below the wastewater discharger according to total phosphorus, total nitrogen and ammonia nitrogen. Below the wastewater discharger, we determined high amounts of the pollutants. No essential differences were established during research of biochemical oxygen demand within 7 days - the amount of organic materials was the same within the period of 2009-2014.

The amount of organic matter in the water was assessed according to the $\mathrm{BOD}_{7}$ index. A change of $\mathrm{BOD}_{7}$ value in Mažoji Sruoja water in 2009-2014 is provided in Figure 4.

During the assessment of $\mathrm{BOD}_{7}$ value change dynamics in 2009-2014, we observed a tendency of a slight decrease both above and below the wastewater treatment facility discharger.

Fig. 4

$\mathrm{BOD}_{7}$ value change in Mažoji Sruoja water in 2009-2014

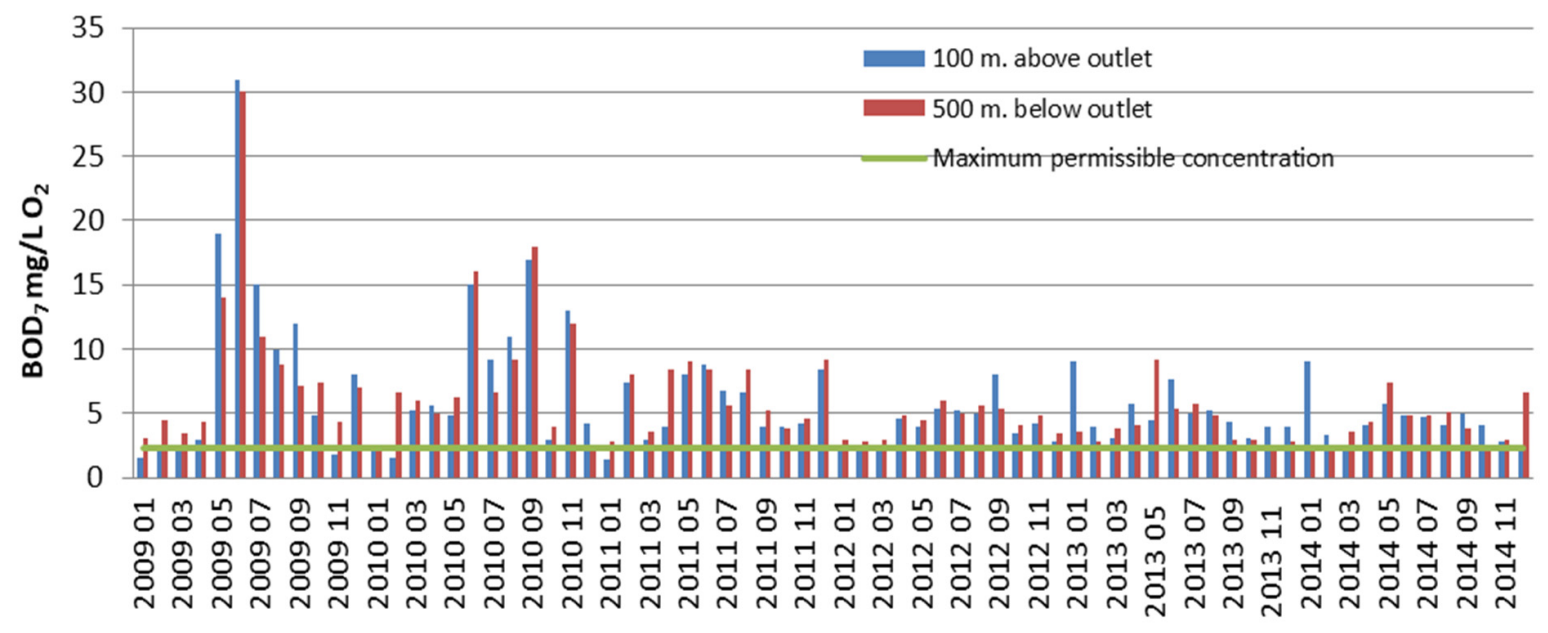


Fig. 5

Total phosphorus (TP) content change in the River Mažoji Sruoja water in 2009-2014

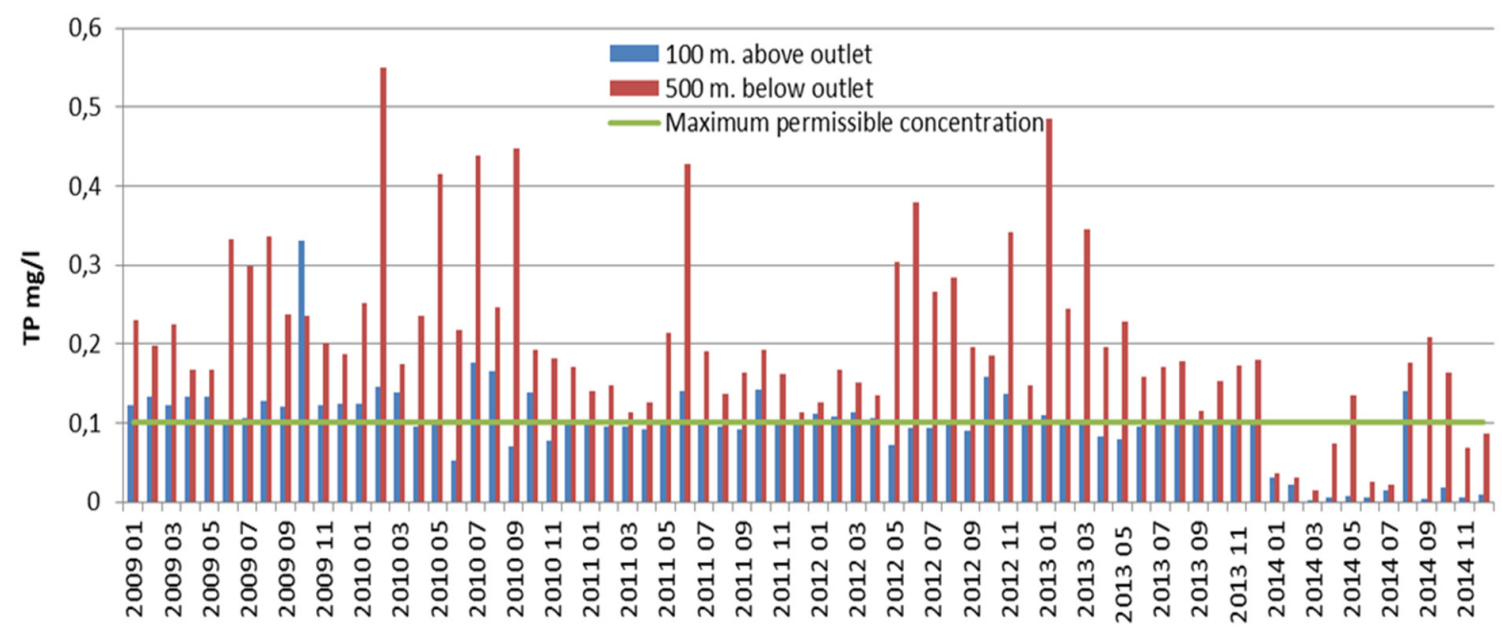

Phosphorus is one of the main biogenic materials predetermining the capacity of the water body. Phosphorus enters surface water from external pollution sources and as the result of internal-secondary pollution. After entering the water, this biogenic material is accumulated in the bottom sediments; however, in some periods, phosphorus generation may exceed its sedimentation. In such cases, the amount of phosphorus in water increases.

To the surface, water phosphorus is washed out from the soil, consisting of rocks, generated as water organism metabolism and degradation by-products, and enters as the result of human economic activity (use of phosphorus fertilisers or detergents). Usually, in surface water bodies, phosphorus is contained in phosphates $\left(\mathrm{PO}_{4}\right)$. Phosphates enter water with wastewater containing phosphorous fertilisers, washing agents containing phosphates and food waste (Ruminaite 2010).

Assessment of the total phosphorus value change dynamics in 2009-2014 showed a tendency of a slight decrease both above and below the wastewater treatment plant discharger (Figure 5).

Assessment of ammonia nitrogen value change dynamics in 2009-2014 demonstrated a tendency of a slight decrease above the wastewater discharger, and an increase below the wastewater discharger (not statistically reliable, low determination coefficient) (Figure 6).

Assessment of the total nitrogen value change dynamics in 2009-2014 showed a tendency of a slight decrease both above and below the wastewater treatment plant discharger (not statistically reliable, low determination coefficient) (Figure 7).

\section{Assessment of the impact of the wastewater treatment plant on the water quality of Mažoji Sruoja}

In order to determine the impact of Plunge wastewater on the quality of Mažoji Sruoja water, we calculated the correlation coefficients between $\mathrm{TN}, \mathrm{NH}-\mathrm{N}$, $\mathrm{TP}$ and $\mathrm{BOD}_{7}$ values in the treated wastewater and the values in Mažoji Sruoja water at the distance of 500 $\mathrm{m}$ below the wastewater discharger. The results are provided in Table 1.

After carrying out the statistical correlation analysis, we established that the wastewater entering the river from Plunge wastewater treatment plant had an impact on the water quality of Mažoji Sruoja. Statistically significant positive correlations within the whole 
Fig. 6

Ammonia nitrogen (NH4-N) content change in the River Mažoji Sruoja water in 2009-2014

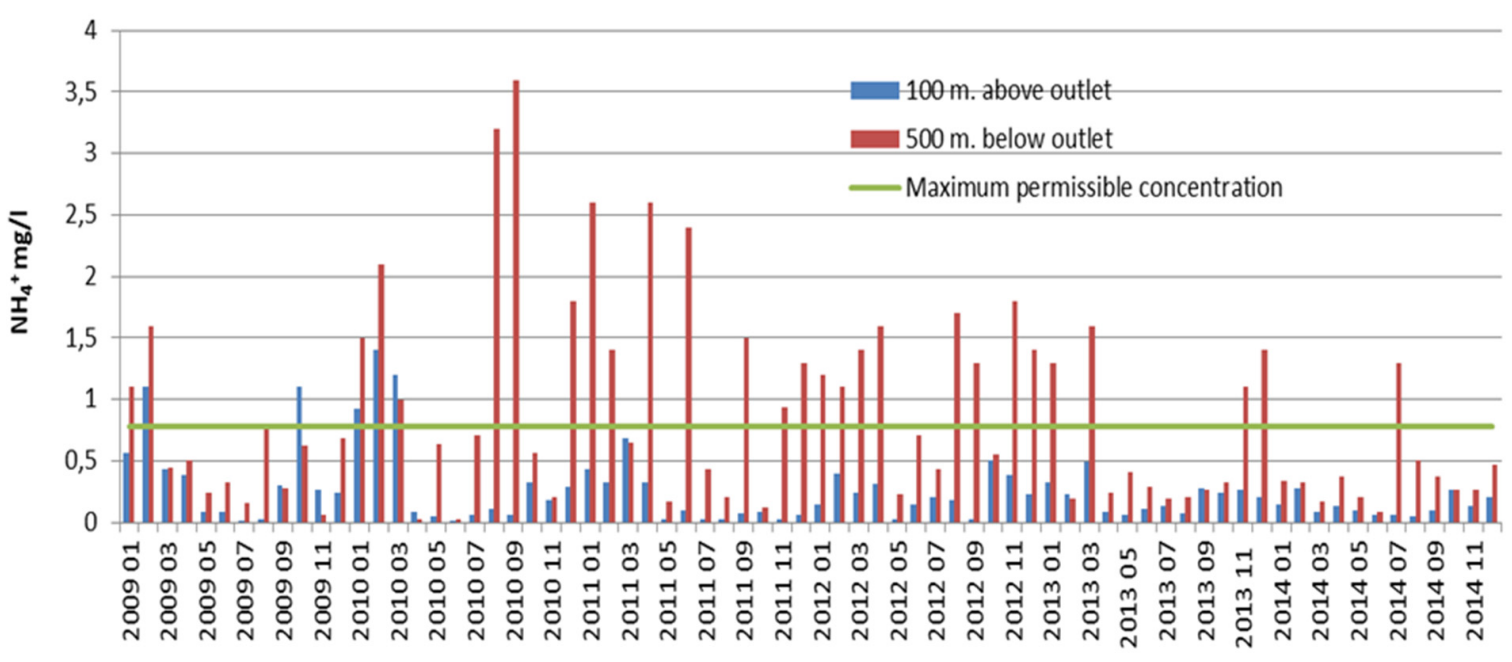

Fig. 7

Total nitrogen (TN) content change in Mažoji Sruoja River water in 2009-2014

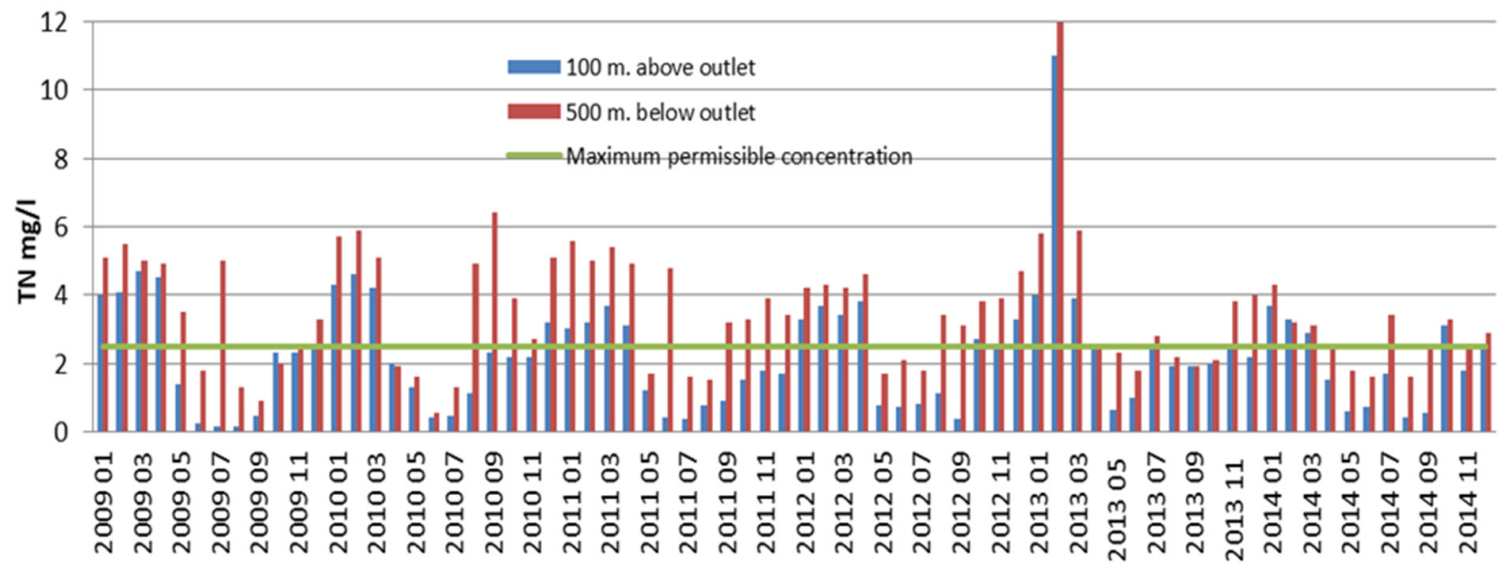

research period were received after treatment and below the wastewater discharger in Mažoji Sruoja water according to the most important pollution indices. It was established that all the studied indices had a major impact on Mažoji Sruoja water in 2014, compared with previous years.
As the values of all the studied indices below the wastewater discharger in Mažoji Sruoja water (especially of biogenic materials) were high, it can be stated that although the wastewater is treated up to permissible levels, it is insufficient for a proper ecological state of the river. 


\section{Table 1}

The correlation matrix of water quality component indices in Mažoji Sruoja water below the discharger and wastewater discharged into the river ( $r$ - correlation coefficient, $p$ - reliability level, $p<0.05$ )

\begin{tabular}{|c|c|c|c|c|c|}
\hline 2009 & 2010 & 2011 & 2012 & 2013 & 2014 \\
\hline 1 & 2 & 3 & 4 & 5 & 6 \\
\hline \multicolumn{6}{|c|}{$\mathrm{TN}$ mg/L } \\
\hline $\begin{array}{l}r=0.60 \\
p>0.05\end{array}$ & $\begin{array}{l}r=0.75 \\
p<0.05\end{array}$ & $\begin{array}{l}r=0.54 \\
p<0.05\end{array}$ & $\begin{array}{l}r=0.83 \\
p<0.05\end{array}$ & $\begin{array}{l}r=0.63 \\
p<0.05\end{array}$ & $\begin{array}{l}r=0.71 \\
p<0.05\end{array}$ \\
\hline \multicolumn{6}{|c|}{$\mathrm{NH}_{4}-\mathrm{N} \mathrm{mg} / \mathrm{L}$} \\
\hline $\begin{array}{l}r=0.38 \\
p<0.05\end{array}$ & $\begin{array}{l}r=0.30 \\
p<0.05\end{array}$ & $\begin{array}{l}r=0.50 \\
p<0.05\end{array}$ & $\begin{array}{l}r=0.63 \\
p<0.05\end{array}$ & $\begin{array}{l}r=0.42 \\
p<0.05\end{array}$ & $\begin{array}{l}r=0.57 \\
p<0.05\end{array}$ \\
\hline \multicolumn{6}{|c|}{ TP mg/L } \\
\hline $\begin{array}{l}r=0.34 \\
p<0.05\end{array}$ & $\begin{array}{l}r=0.61 \\
p<0.05\end{array}$ & $\begin{array}{l}r=0.49 \\
p<0.05\end{array}$ & $\begin{array}{l}r=0.60 \\
p<0.05\end{array}$ & $\begin{array}{l}r=0.56 \\
p<0.05\end{array}$ & $\begin{array}{l}r=0.55 \\
p<0.05\end{array}$ \\
\hline \multicolumn{6}{|c|}{$\mathrm{BOD}_{7} \mathrm{mg} \mathrm{O}_{2} / \mathrm{L}$} \\
\hline $\begin{array}{l}r=0.43 \\
p<0.05\end{array}$ & $\begin{array}{l}r=0.27 \\
p>0.05\end{array}$ & $\begin{array}{l}r=0.32 \\
p<0.05\end{array}$ & $\begin{array}{l}r=0.52 \\
p<0.05\end{array}$ & $\begin{array}{c}r=0.6 \\
p<0.05\end{array}$ & $\begin{array}{l}r=0.52 \\
p<0.05\end{array}$ \\
\hline
\end{tabular}

\section{Seasonal differences in the water quality of Mažoji Sruoja}

The water quality differences of Mažoji Sruoja were studied during different seasons of the year. $\mathrm{BOD}_{7}$ maximum values above and below the wastewater discharger were determined in summer, and minimum values were obserbed in winter. In autumn and spring, a $\mathrm{BOD}_{7}$ change remained regulated both above and below the wastewater treatment facility discharger (Figure 8). This fact can be explained by the low water level in the river during the dry period of the

Fig. 8

BOD7 values in Mažoji Sruoja water above (a) and below (b) the wastewater treatment plant discharger

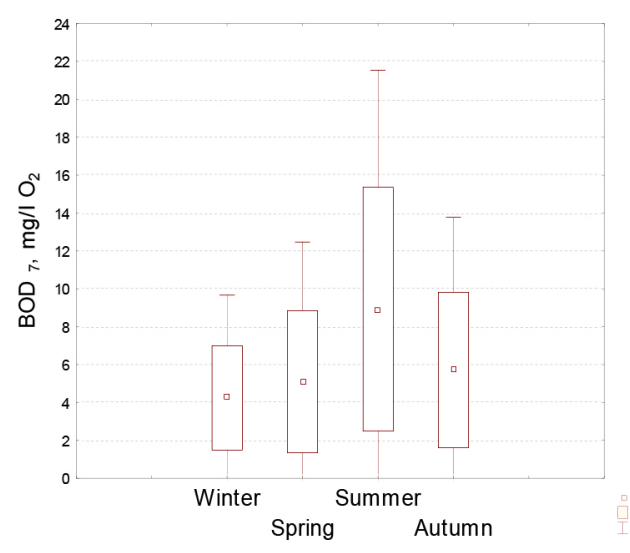

a

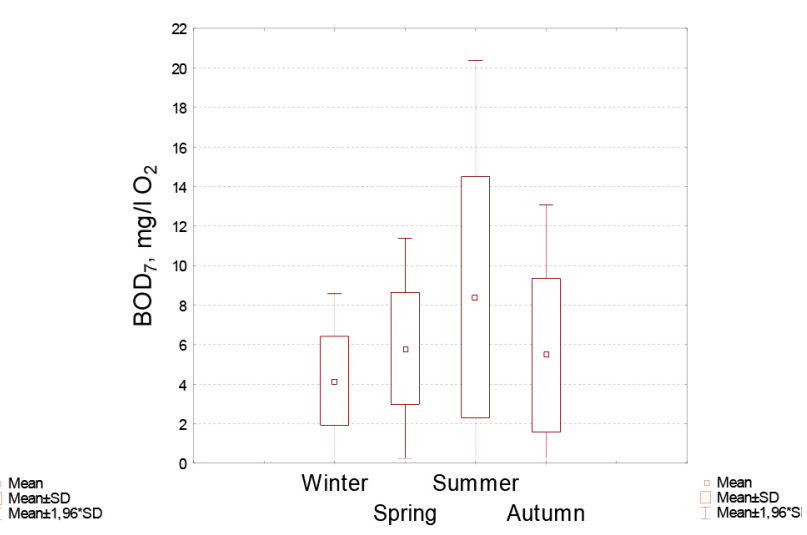

b 
year and low permeability capacity and intensive flora and fauna activity.

It is possible to distinguish insignificant seasonality of total phosphorus in Mažoji Sruoja. Total phosphorus content values were minor above the wastewater treatment plant discharger during winter; and in autumn, a greater amount was observed. The maximum amount was observed below the wastewater discharger in summer, and the minimum in winter (Figure 8).

Phosphorus compound concentration in surface water depends on the season. In spring, when photosynthesis is intensive, and in summer, during the vegetation period, the concentration of these materials significantly decreases, and during the cold season of the year, during the oxidation of organic materials, the amount of phosphorus compounds increases gradually (Ruminaite 2010). The fact of determination of a high total phosphorus content below the wastewater discharger in summer demonstrates the impact of point source pollution (Figure 9).

Seasonal changes are usual for all forms of nitrogen compounds in natural water (Ruminaite 2010). The maximum ammonia nitrogen contents were observed in winter. In autumn and spring, ammonia nitrogen concentrations were almost the same, and in summer they were minor.
Below the wastewater discharger, the minimum ammonia nitrogen concentrations were observed in spring, and the maximum concentrations were determined in winter (Figure 10).

The total nitrogen content in Mažoji Sruoja water was minor in spring above the wastewater discharger. In spring and autumn, seasonal concentrations insignificantly increased; and in winter, we observed the maximum concentration of total nitrogen. A similar tendency was observed below the wastewater discharger, and only the total nitrogen content significantly increased, especially in summer (Figure 11).

As already mentioned, minimum concentrations of biogenic materials are usually observed during the vegetation period, when there is intensive photosynthesis. During the cold season of the year, during the oxidation of organic materials and mineralization processes, the content of biogenic materials increases gradually. Significant seasonal changes in the biogenic matter content are a response of an ecosystem of water bodies to the excessive content of mineral and organic materials (Ruminaite 2010). During the research, changes in concentrations of nitrogen compounds mainly reflected the seasonal changes in Mažoji Sruoja water.

Fig. 9

Change of total phosphorus (TP) concentrations in Mažoji Sruoja water above (a) and below (b) the wastewater treatment plant discharger

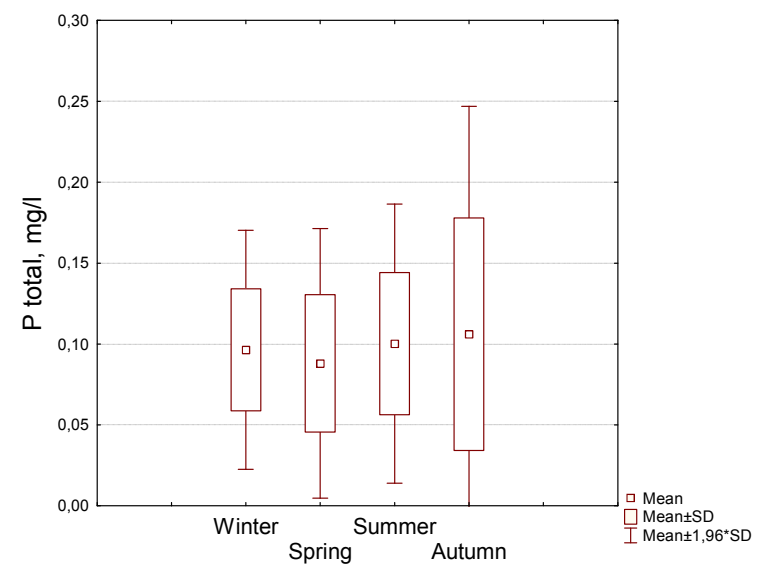

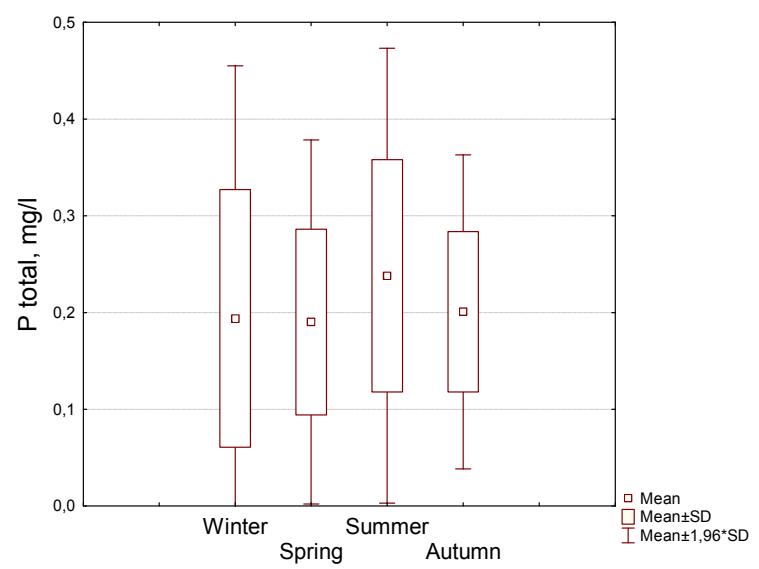

b 
Fig. 10

Change of ammonia nitrogen $\left(\mathrm{NH}_{4}-\mathrm{N}\right)$ concentrations in Mažoji Sruoja water above (a) and below (b) the wastewater treatment plant discharger

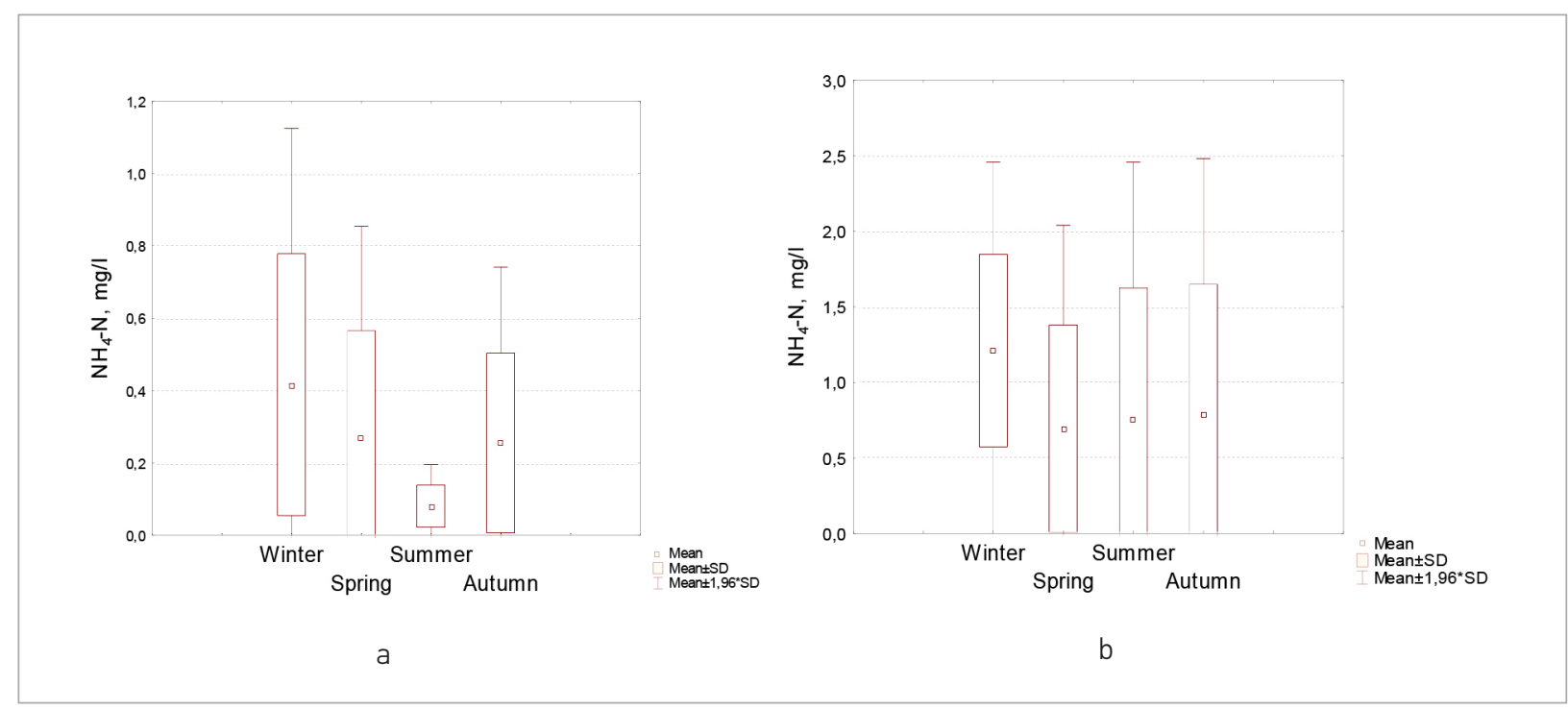

Fig. 11

Change of total nitrogen (TN) concentrations in Mažoji Sruoja water above (a) and below (b) the wastewater treatment plant discharger

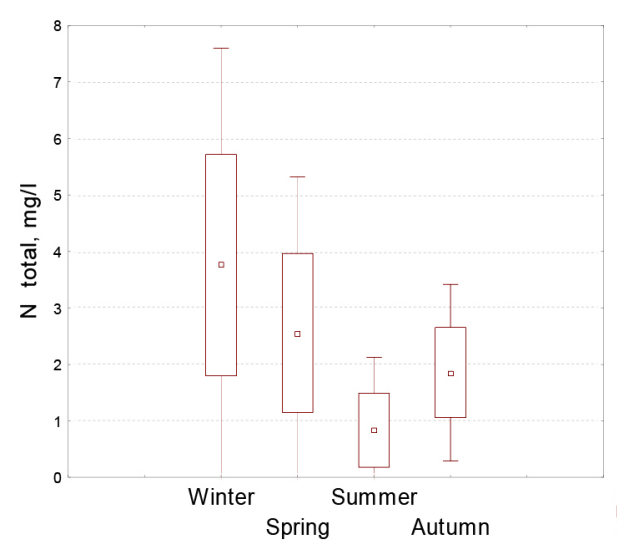

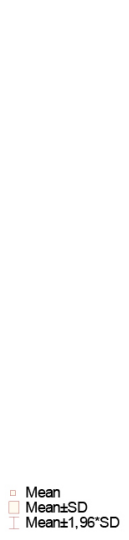

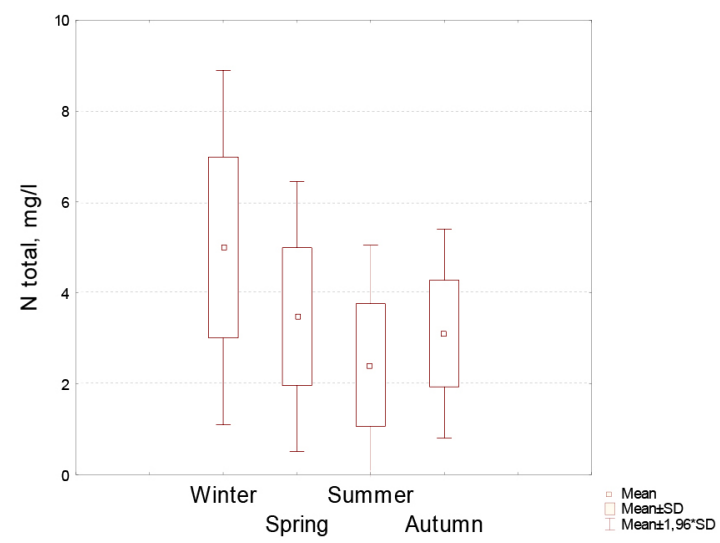

b

\section{Conclusions}

Essential differences above and below the wastewater discharger according to total phosphorus, total nitrogen and ammonia nitrogen were established in the water of the River Mažoji Sruoja in 2009-2014. The $\mathrm{BOD}_{7}$ index difference was insignificant.
Plunge wastewater has an impact on the quality of Mažoji Sruoja water. The statistically significant positive correlation $(p<0.05)$ between treated wastewater and concentration indices of the tested river water quality below the discharger of 
the wastewater treatment facility was identified. Changes in concentrations of nitrogen compounds especially reflected the seasonal changes in Mažoji Sruoja water. The seasonality of total phosphorus was insignificant. High total nitrogen concentrations were observed below the wastewater discharger in summer.
Although wastewater is treated in Plunge wastewater treatment plant up to permissible levels, it is insufficient for a proper ecological state of the River Mažoji Sruoja. The wastewater treatment plant should ensure more effective removal of biogenic materials and especially phosphorus.

\section{References}

Bagdžiūnaitè - Litvinaitienè L., Lukianas A. (2004). Fluctuacions of nitrogen and phosphorus compounds concentrations in river water. Water Management Engineering 25(45): 99 - 110 (in Lithuanian).

Burkholder J., Libra B., Weyer P., Heathcote S., Kolpin D., Thorne P.S., and Wichman M. (2007). Impacts of waste from concentrated animal feeding operations on water quality. Environ Health Perspectives 115(2): 308-12. https://doi.org/10.1289/ehp.8839 Carpenter, S. R., N. F. Caraco, D. L. Correll, R. W. Howarth, A. N. Sharpley, and V. H. Smith. 1998. Nonpoint pollution of surface waters with phosphorus and nitrogen. Ecological Applications 8: 559-568. http://dx. doi: 10.1890/1051-0761(1998)008[0559:NPOSWW]2.0.CO;2.

Cooper, C. M. (1993). Biological effects of agriculturally derived surface water pollutants on aquatic systems - a review. Journal of Environmental Quality 22: 402-408. https://doi. org/10.2134/jeq1993.00472425002200030003x

Environmental Protection Agency (EPA). Review of surface water bodies protection problems of Nemunas river basin district. Vilnius, p.127 (In Lithuanian).

Gailiušis, B., Jablonskis, J., Kovalenkovienè, M. (2001). Lithuanian river (Hydrography and runoff): Monograph. Kaunas: Lithuanian Energy Institute, 769. (in Lithuanian).

Grimvall A., Stalnacke P., Tonderski A. (2000). Time Scale of Nutrient Losses from Land to Sea-a European Perspective. Ecological Engineering. 14: 363-371. http://moritz.botany. ut.ee/ olli/eutrsem/Grimvall00.pdf. https://doi.org/10.1016/ S0925-8574(99)00061-0

Jurjoniene V., Valatka E. (1997). The Evaluation of Impact of Kaunas Waste Water on Quality of the Nemunas River Water. Environmental Research, Engineering and Management 1(4): 32-35 (in Lithuanian).

Kronvang, B., Hans E. Andersen, H.E., Børgesen, C., Dalgaard, T., Larsen, S. E., Bøgestrand, J., Blicher-Mathiasen, G. (2008). Effects of policy measures implemented in Denmark on nitrogen pollution of the aquatic environment. Environmental Science \& Policy 11(2): 144-152. http://eva.universidad.edu.uy/file.php/1426/ PAPERS/papers/Kronvang_et_al_2008_Environ_Science_Policy.pdf. https://doi.org/10.1016/j.envsci.2007.10.007

Kelly, M., H. Bennion, A. Burgess, J. Ellis, S. Juggins, R. Guthrie,
J. Jamieson, V. Adriaenssens \& M. Yallop, (2009). Uncertainty in ecological status assessments of lakes and rivers using diatoms. Hydrobiologia. https://doi.org/10.1007/s10750-009-9872-z

Kronvang, B., Jeppesen, E., Conley, D.J, Søndergaard, M., Larsen, S.E., Ovesen, N.B., J. Carstensen, J. (2005). Nutrient pressures and ecological responses to nutrient loading reductions in Danish streams, lakes and coastal waters. Journal of Hydrology, 304: 274-288. http://citeseerx.ist.psu.edu/ viewdoc/download?doi=10.1.1.177.7449\&rep=rep $1 \&$ type $=$ pdf https://doi.org/10.1016/j.jhydrol.2004.07.035

Ministry of Environment of the Republic of Lithuania. Description of procedure of surface water ecological status assessment (2011). Žinios, 2011, Nr. 109-5146. (in Lithuanian).

Ministry of Environment of the Republic of Lithuania. The State of Environment 2012. Only facts. (in Lithuanian).

Matysik, M., Atsalon,D., Ruman, M. (2015)Surface Water Quality in Relation to Land Cover in Agricultural Catchments (Liswarta River Basin Case Study) Pol. J. Environ. Stud. 24 (1), 175-184. https://doi.org/10.15244/pjoes/26203

Nõges P., Van de Bund W., Cardoso A.K., Solimini A.G., Heiskanen A.S. 2009 Assessment of the ecological status of European surface waters: a work in progress. Hydrobiologia, 633 (1), 197-211. https://doi.org/10.1007/s10750-009-9883-9

Povilaitis, A. (2008). Source apportionment and retention of nutrients and organic matter in the merkys river basin in southern Lithuania. Journal of Environmental Engineering and Landscape Management 16(4): 195-204. https://doi.org/10.3846/16486897.2008.16.195-204

Ruminaitè, R. (2010). Water runoff and pollution peculiarities in Lielupe watershed per 1992-2006 year period. Water Management Engineering 36(56): 100-108 (in Lithuanian).

Ruminaite, R. (2010). Research and evaluation of the anthropogenic activity impact on the river runoff and water quality. Doctoral dissertation. Vilnius, Technika, p. 183 (in Lithuanian). http://vddb.laba.lt/fedora/get/LT-eLABa-0001:E.02 2010 D_20101222_130641-59851/DS.005.0.01.ETD.

Vincevičienè V., Asadauskaite A. (2000). Assessment of Point Pollution and Impact to Water Quality of the Transboundary River Basins-the Venta and the Musa-Lielupe. Environmental Research, Engineering and Management. 1(11): 41-51. 


\section{Plungès miesto nuotekų poveikis Mažosios Sruojos upès vandens kokybei}

\section{Laima Česonienè}

Aplinkos ir ekologijos institutas, Aleksandro Stulginskio Universitetas, Studentu g. 11, LT-53361, Kaunas

\section{Midona Dapkienè}

Hidrotechnikos institutas, Aleksandro Stulginskio Universitetas, Studentu g. 11, LT-53361, Kaunas

\section{Daiva Šileikienè}

Aplinkos ir ekologijos institutas, Aleksandro Stulginskio Universitetas, Studentu g. 11, LT-53361, Kaunas

\section{Vaiva Rekašienè}

UAB "Plungès vandenys", Medelyno g. 41, Noriškių k., Plungès raj., LT-90103

Neigiamą poveiki Lietuvos paviršinių vandens telkinių būklei daro tiek pasklidoji tarša, tiek ir sutelktoji tarša, ypač tarša biogeninemis medžiagomis. Didelè teršalų dalis i paviršinius vandens telkinius patenka su buitinemis nuotekomis iš Lietuvos miestų. Straipsnyje analizuojamas Plungès miesto nuotekų poveikis Mažosios Sruojos upés vandens kokybei.

Mažosios Sruojos upės vandenyje 2009-2014 m. laikotarpiu nustatyti esminiai taršos skirtumai 100 m aukščiau nuoteku išleistuvo ir $500 \mathrm{~m}$ žemiau nuoteku išleistuvo pagal bendraji fosforą, bendraji azotą, amonio azotą. Nustatyta, kad upės vandens kokybe kinta skirtingu sezonų metu. Pastebètas taršos bendruoju azoto sezoniškumas tirtos upès vandenyje.

Plungès miesto nuotekos daro poveiki Mažosios Sruojos upes vandens kokybei. Nustatyta statistiškai reikšminga teigiama koreliacija $(p<0,05)$ tarp išvalytų nuotekų ir visų tirtų upės vandens kokybės rodiklių koncentraciju žemiau nuotekų išleistuvo. Kritulių kiekis turi j̇takos Mažosios Sruojos upės vandens kokybei tik 100 m aukščiau išleistuvo.

Raktiniai žodžiai: nuotekų valymo irenginiai, upių vandens kokybè, biogeninès medžiagos. 